\title{
OPTIMASI SUHU DAN LAMA FERMENTASI \\ TEPUNG KACANG NAGARA (Vigna Unguiculata ssp. Cylindrica) MENGGUNAKAN Lactobacillus plantarum DENGAN RESPONSE SURFACE METHODOLOGY (RSM) \\ OPTIMIZATION OF TEMPERATURE AND FERMENTATION DURATION OF NAGARA BEAN FLOUR (Vigna Unguiculata ssp. Cylindrica) USING Lactobacillus plantarum WITH RESPONSE SURFACE METHODOLOGY (RSM)
}

\author{
Susi $^{1{ }^{*}}$, Lya Agustina ${ }^{1)}$, Condro Wibowo ${ }^{2)}$, Alia Rahmi ${ }^{1)}$, Umar Dani Anshory ${ }^{1)}$ \\ 1) Jurusan Teknologi Industri Pertanian, Universitas Lambung Mangkurat \\ Jl. A Yani KM 36 Banjarbaru Kalimantan Selatan 70714 \\ Email: susi_tip@ulm.ac.id \\ ${ }^{2)}$ Program Studi Ilmu dan Teknologi pangan, Universitas Jenderal Soedirman, Purwokerto, Jawa Tengah Indonesia \\ Makalah: Diterima 10 Juli 2018; Diperbaiki 7 November 2018; Disetujui 17 Desember 2018
}

\begin{abstract}
Nagara bean (Vigna Unguiculata ssp. Cylindrica)is local food ingredients that has the potential to be developed for food diversification because it predominantly contains carbohydrates (50-60\%) and protein (2025\%). Previous research showed that fermentation of nagara bean with Lactobacillus plantarum at room temperature can improve the characteristic of nagara bean flour.The research was aimed to optimize the temperature and fermentation duration of nagara bean byL. plantarum for modification of nagara bean flour using the Response Surface Methodology (RSM) method. Fermentation using L. plantarum bacteria as much as $1 \%(v / v)$ on nagara bean grits using a ratio of nagara bean and soaking water $=1:$ 4.The research factor used was periods and soaking temperature with each center point 48 hours and $37{ }^{\circ} \mathrm{C}$ respectively. The result of research showed that the optimumtemperature and fermentation durationswere $39.14^{\circ} \mathrm{C}$ and 49.71 hours with the result in water absorption index (IPA) of 2.03, swelling power of $5.13 \mathrm{~g} / \mathrm{g}$ and protein content of $25.60 \%$ while factor (treatment) temperature and fermentation duration did not give significant effect to density, insoluble solid, moisture content, ash content, fat content and carbohydrate content.
\end{abstract}

Keywords: Nagara bean, fermentation, Lactobacillus plantarum, Response Surface Methodology

\section{ABSTRAK}

Kacang nagara (Vigna Unguiculata ssp. Cylindrica) merupakan pangan lokal yang potensial dikembangkan sebagai wujud diversifikasi pangan karena dominan mengandung karbohidrat (50-60\%) serta protein (20-25\%). Penelitian terdahulu menunjukkan fermentasi kacang nagara dengan Lactobacillus plantarum pada suhu ruang mampu meningkatkan karakteristik tepung kacang nagara. Penelitian ini bertujuan melakukan optimasi lama dan suhu fermentasi kacang nagara menggunakan $L$. plantarum untuk modifikasi tepung kacang nagara dengan metode Response Surface Methodology (RSM). Fermentasi menggunakan bakteri laktat $L$. plantarum sebanyak $1 \%(\mathrm{v} / \mathrm{v})$ pada grits kacang nagara menggunakan perbandingan kacang nagara dan air perendam = 1:4 dengan RSM. Faktor penelitian yang digunakan lama dan suhu perendaman dengan titik tengah (center point) masing-masing 48 jam dan $37^{\circ} \mathrm{C}$. Hasil penelitian menunjukkan lama dan suhu fermentasi optimum pada lama fermentasi 49,71 jam dan suhu fermentasi $39,14^{\circ} \mathrm{Cdengan}$ menghasilkan indeks penyerapan air (IPA) sebesar 2,03, swelling power sebesar 5,13 g/g dan kadar protein sebesar 25,60\%. Faktor (perlakuan) lama dan suhu fermentasi tidak memberikan pengaruh yang nyata terhadap densitas kamba, padatan tidak larut, kadar air, kadar abu, kadar lemak dan kadar karbohidrat.

Kata kunci: Kacang nagara, fermentasi, Lactobacillus plantarum, Response Surface Methodology

\section{PENDAHULUAN}

Kebijakan percepatan Penganekaragaman Konsumsi Pangan Berbasis Sumber Daya Lokal yang tertulis dalam Peraturan Presiden RI Nomor 22 tahun 2009 merupakan strategi untuk mengatasi ketergantungan masyarakat terhadap jenis bahan pangan pokok beras dan terigu. Bentuk kebijakan yang dilakukan yaitu melalui program percepatan diversifikasi konsumsi pangan. Salah satu bahan pangan lokal yang dominan mengandung protein serta karbohidrat yang tinggi adalah kacang nagara,oleh karena itu kacang nagara dapat dijadikan sumber karbohidrat non beras berbasis sumberdaya lokal.

Kelemahan dari kacang-kacangan adalah adanya kandungan senyawa anti gizi yang sebagian besar didominasi oleh asam fitat (Astawan, 2009) dan bau langu yang mengakibatkan produk akhir menjadi kurang diterima masyarakat. Asam fitat akan membentuk ikatan kompleks dengan zat besi atau mineral lain, seperti seng, magnesium, dan 
kalsium, menjadi bentuk yang tidak larut dan sulit diserap tubuh (Suhanda, 2009). Kandungan antigizi maupun bau langu dapat berkurang atau dihilangkan melalui proses perendaman, pemanasan maupun fermentasi. Secara tradisional, proses fermentasi banyak digunakan untuk proses produksi tepung dan adonan dari umbi-umbian dan serealia pada skala rumah tangga di Afrika.

Fermentasi produk pangan banyak melibatkan bakteri asam laktat, salah satunya Lactobacillus plantarum. Bakteri L. plantarum memiliki aktivitas amilase yang mampu mendegradasi pati yang ada pada bahan pangan menjadi asam laktat maupun monosakarida yang akan lebih mudah untuk dimanfaatkan oleh tubuh dan meningkatkan penggunaan pati. (Nowroozi et al., 2004). Menurut Bergey dan Boone (2009) L. plantarum dapat memfermentasi karbohidrat seperti amygdalin, sellobiosa, esculin, glukonat, mannitol, melibiose, rafinosa, ribose, sorbitol, sukrosa, dan xilosa hingga 90\%. Bakteri asam laktat amilolitik banyak digunakan untuk memperoleh produk sereal kaya energi melalui peningkatan pati yang mudah tercerna (Nguyen et al., 2007). Fermentasi menggunakan $L$ plantarum dapat meningkatkan swelling power dan kelarutan serta kandungan pati singkong (Putri et al., 2011), memiliki kandungan protein lebih tinggi jika dibandingkan fermentasi menggunakan $\mathrm{S}$. cereviceae dan $\mathrm{R}$. oryzae (Gunawan, 2015).

Susi et al. (2015) telah melakukan modifikasi tepung kacang nagara sebagai bahan baku beras analog melalui fermentasi spontan dan menggunakan Lactobacillus plantarum dengan variasi perlakuan lama perendaman dan ukuran kacang nagara yang dilakukan pada suhu ruang. Hasil fermentasi tepung kacang nagara menunjukkan bahwa fermentasi menggunakan $L$. plantarum pada lama perendaman 48 jam cenderung mampu menghasilkan kualitas tepung yang lebih baik. Fermentasi tepung kacang nagara mampu meningkatkan kandungan protein dari $17 \%$ menjadi $24 \%$ serta menghasilkan daya cerna pati $82,69 \%$. Proses fermentasi kacang nagara dengan $L$. plantarum dapat dioptimalkan dengan meningkatkan suhu fermentasi menjadi $37^{\circ} \mathrm{C}$ karena suhu tersebut merupakan suhu optimum untuk pertumbuhan $L$. plantarum. Oleh karena itu, perlu dilakukan suatu penelitian dengan menggunakan model matematika yang menyatakan hubungan kombinasi perlakuan lama dan suhu perendaman selama fermentasi sehingga dapat diketahui kondisi modifikasi tepung kacang nagara melalui fermentasi Lactobacillus plantarum yang menghasilkan karakteristik tepung kacang nagara yang optimum. Salah satu metode yang dapat dipilih adalah menggunakan Response Surface Methodology (RSM).

Penelitian ini bertujuan menentukan lama dan suhu fermentasi optimum menggunakan Lactobacillus plantarum untuk modifikasi tepung kacang nagara dengan metode RSM untuk mendapatkan sifak fisikokimia indeks penyerapan air, swelling power dan kandungan protein yang terbaik.

\section{BAHAN DAN METODE}

\section{Bahan dan Alat}

Bahan yang digunakan adalah kacang nagara dari daerah Nagara Kabupaten Hulu Sungai Selatan, bakteri Lactobacillus plantarum $1 \%(v / v)$, aquades, kloroform, $\mathrm{K}_{2} \mathrm{SO}_{4}, \mathrm{CuSO}_{4}, \mathrm{H}_{2} \mathrm{SO}_{4}, \mathrm{H}_{2} \mathrm{O}_{2}$, $\mathrm{Na}_{2}\left(\mathrm{SO}_{4}\right)_{3}$ dan $\mathrm{HCl}$. Alat-alat yang digunakan adalah disc mill, neraca analitik, water bath, autoclave, oven, saringan dengan ukuran 80 mesh, sentrifuge, gelas ukur, gelas beaker, cawan porselen, tanur, labu kjeldahl, labu lemak, soxhlet, reflux dan Software Minitab 17

\section{Penentuan Respon, Faktor dan Titik Tengah (Center Point)}

Data yang digunakan untuk menentukan titik tengah dalam penelitian ini merupakan data sekunder hasil penelitian modifikasi tepung kacang nagara melalui fermentasi bakteri asam laktat yang dilakukan oleh Susi et al. (2015b). Selain itu beberapa penelitian terkait pemanfaatan bakteri Lactobacillus plantarum juga dijadikan data dalam penelitian ini yaitu penelitian Afriani (2010); Mangalisu et al. (2015) dan Nurani et al. (2013) untuk menentukan faktor penelitian yaitu lama dan suhu perendaman dengan titik tengah (center point) masing-masing 48 jam dan $37^{\circ} \mathrm{C}$ (rancangan faktor perlakuan dapat dilihat pada Tabel 1). Respon dalam penelitian ini adalah kualitas fisik mencakup densitas kamba, indeks penyerapan air, swelling power dan bagian tidak larut air serta kimia mencakup kadar air, kadar abu, kadar lemak, kadar protein dan kadar karbohidrat.

\section{Fermentasi Bakteri Asam Laktat Kacang Nagara}

Fermentasi menggunakan bakteri laktat $L$. plantarum dengan jumlah $8,8 \times 10^{6} \mathrm{CFU} / \mathrm{mL}$ yang ditambahkan sebanyak $1 \%(\mathrm{v} / \mathrm{v})$ padagrits kacang nagara menggunakan perbandingan kacang nagara : air perendam $=1: 4$. dengan lama fermentasi 48 jam. Kacang nagara hasil fermentasi dicuci bersih dan dihilangkan dari kulitnya kemudian dikeringkan pada suhu $60^{\circ} \mathrm{C}$ selama 48 jam. Kacang nagara hasil fermentasi ditepungkan dengan ukuran 80 mesh.

\section{Densitas Kamba (Adeleke dan Odejeji, 2010)}

50 gram sampel dimasukkan ke dalam gelas ukur $100 \mathrm{~mL}$ dan dicatat volume tetapnya. Densitas kamba dinyatakan dalam satun $\mathrm{g} / \mathrm{cm}^{3}$ atau $\mathrm{g} / \mathrm{mL}$.

$$
\text { Densitas } k a m b a=\frac{\text { berat sampel }}{\text { volume sampel }}
$$


Tabel 1. Rancangan faktor perlakuan

\begin{tabular}{ccccc}
\hline \multirow{2}{*}{ Run } & \multicolumn{2}{c}{ Faktor Kode } & \multicolumn{3}{c}{ Faktor Aktual } \\
\cline { 2 - 5 } & X1 & $\mathbf{X 2}$ & Lama Fermentasi (jam) & Suhu Fermentasi $\left({ }^{\mathbf{0}} \mathbf{C}\right)$ \\
\hline 1 & -1 & -1 & 24 & 27 \\
2 & 1 & -1 & 72 & 27 \\
3 & -1 & 1 & 24 & 47 \\
4 & 1 & 1 & 72 & 47 \\
5 & $-1,414$ & 0 & 14,05 & 37 \\
6 & 1,414 & 0 & 81,94 & 37 \\
7 & 0 & $-1,414$ & 48 & 22,85 \\
8 & 0 & 1,414 & 48 & 51,14 \\
9 & 0 & 0 & 48 & 37 \\
10 & 0 & 0 & 48 & 37 \\
11 & 0 & 0 & 48 & 37 \\
12 & 0 & 0 & 48 & 37 \\
13 & 0 & 0 & 48 & 37 \\
\hline
\end{tabular}

\section{Indeks Penyerapan air (Muchtadi et al., 1988)}

Sebanyak $1 \mathrm{~g}$ sampel yang sudah ditepungkan (A) dimasukkan dalam tabung sentrifus, setelah itu ditambah $10 \mathrm{~mL}$ aquades dan diaduk dengan menggunakan vibrator sampai semua bahan terdispersi secara merata. Tabung selanjutnya disentrifugasi dengan kecepatan $2000 \mathrm{rpm}$ pada suhu ruang selama 15 menit. Supernatan yang diperoleh dituang secara hati-hati ke dalam wadah lain,sedangkan tabung sentrifus beserta residunya dipanaskan dalam oven. Tabung diletakkan dalam oven yang diatur pada suhu $50^{\circ} \mathrm{C}$ selama 25 menit. Akhirnya tabung residu ditimbang untuk menentukan berat air yang terserap (B).

$$
\text { Indeks penyerapan air } g / g=\frac{\text { berat air yang terserap }(\mathrm{g})}{\text { berat awal }(\mathrm{g})}
$$

\section{Swelling Power (Adeleke dan Odejeji, 2010)}

Ditimbang bahan sebanyak 1 g dan dimasukkan ke dalam gelas beker, kemudian ditambahkan $15 \mathrm{~mL}$ air dan dipanaskan pada suhu $80-85^{\circ} \mathrm{C}$ selama 40 menit sambil diaduk. Selanjutnya, campuran disentrifus selama 20 menit pada $2200 \mathrm{rpm}$ pada tabung sentrifus yang sudah ditimbang untuk memisahkan antara padatan dengan cairannya. Pasta pati yang diperoleh ditimbang beratnya.

$$
\text { Swelling volume } g / g=\frac{\text { berat pasta }(g)}{\text { berat awal }(g)}
$$

\section{Bagian Tidak Larut Air (SNI 01-2891-1992)}

Ditimbang kurang lebih $20 \mathrm{~g}$ sampel, dimasukkan ke dalam gelas beker $400 \mathrm{~mL}$, ditambahkan $200 \mathrm{~mL}$ air panas, diaduk hingga larut. Dalam keadaan panas, dituangkan bagian yang tidak larut ke dalam kertas saring yang telah dikeringkan dan ditimbang sebelumnya. Dibilas gelas beker dan kertas saring dengan air panas. Dikeringkan kertas saring dalam oven pada suhu $105^{\circ} \mathrm{C}$ selama dua jam, didinginkan dan ditimbang sampai bobot tetap.

$$
\text { Bagian tidak larut }(\%)=\frac{W 1-W 2}{W} \times 100 \%
$$

Keterangan:

$\mathrm{W}=$ Berat sampel

$\mathrm{W} 1=$ Berat kertas saring berisi bagian tidak larut $\mathrm{W} 2=$ Berat kertas saring kosong

Karakteristik kimia dilakukan pengujian terhadap kadar air, kadar abu, kadar lemak, kadar protein serta kadar karbohidrat by difference (AOAC, 2000).

\section{HASIL DAN PEMBAHASAN}

\section{Densitas Kamba}

Densitas kamba tepung kacang nagara yang dihasilkan berkisarantara $0,62-0,74 \mathrm{~g} / \mathrm{mL}$ hal ini sesuai dengan pendapat Hastawan dan Hazmi (2016), di mana densitas kamba tepung umumnya berkisar antara 0,40-0,75 g/mL akan tetapi jika dibandingkan dengan tepung kacang hijau yang dihasilkan Nurhidajah et al. (2010) dengan densitas kamba berkisar 0,86-0,90 g/mL, densitas kamba tepung kacang nagara yang dihasilkan relatif lebih kecil. Bahan dengan densitas kamba yang kecil akan membutuhkan tempat yang lebih luas dibandingkan dengan bahan dengan densitas kamba yang besar untuk berat yang sama sehingga tidak efisien dari segi tempat penyimpanan dan kemasan (AdeOmowaye et al., 2008).

Hasil optimasi menggunakan RSM menunjukkan bahwa tidak satupun model baik linear maupun square (kuadratik) yang tepat untuk respon densitas kamba. Hal ini dilihat dari nilai $p$-value untuk model linier maupun square lebih besar dari $\alpha$ $=5 \%$, menunjukkan bahwa faktor-faktor (variabel bebas) yaitu lama $\left(x_{1}\right)$ dan suhu fermentasi $\left(x_{2}\right)$ tidak memberikan pengaruh yang nyata terhadap respon yaitu densitas kamba sehingga tidak dapat ditentukan lama dan suhu optimum yang dapat mengoptimalkan densitas kamba. Model yang diperoleh untuk densitas kamba (y) adalah: 
$\mathrm{y}=1,019-0,00619 \mathrm{x}_{1}-0,0109 \mathrm{x}_{2}+0,000025 \mathrm{x}_{12}+$ $0,000090 \mathrm{x}_{22}+0,000079 \mathrm{x}_{1} \mathrm{x}_{2}$

Densitas kamba merupakan bobot massa tepung per satuan volume, densitas tepung kacang nagara hasil fermentasi menunjukkan tidak signifikan berbeda dengan demikian perbedaan suhu dan fermentasi yang dikenakan pada proses fermentasi tidak cukup banyak berpengaruh terhadap nilai densitas Kamba tepung yang dihasilkan.

\section{Indeks Penyerapan Air (IPA)}

Indeks penyerapan air (IPA) menunjukkan kemampuan produk untuk mengikat air. Model yang tepat untuk respon IPA adalah square (kuadratik). Hal ini dilihat dari nilai $p$-value untuk model linier lebih besar dari $\alpha=5 \%$ yaitu 0,385 sedangkan $p$-value untuk model square adalah 0,006 atau lebih kecil dari $\alpha=5 \%$. Untuk kecocokan model, dapat dilihat $p$-value dari model dimana nilai $p$-value $=0,028$ lebih kecil dari derajat signifikansi $\alpha$ $=5 \%$, hal ini berarti faktor-faktor (variabel bebas) memberikan pengaruh yang berarti dalam model sedangkan $p$-value lack-of-fit lebih besar dari $\alpha=5 \%$ yaitu 0,132 artinya tidak ada ketidaksesuaian dalam model. Model yang diperoleh untuk indeks penyerapan air (y) adalah: $\mathrm{y}=0,255+0,01566 \mathrm{x}_{1}+0,0711 \mathrm{x}_{2}-0,000183 \mathrm{x}_{1}^{2}-$

$0,000965 \mathrm{x}_{2}^{2}+0,000074 \mathrm{x}_{1} \mathrm{x}_{2}$

Berdasarkan persamaan diatas, faktor tunggal nya $x_{I}$ (lama fermentasi) dan $x_{2}$ (suhu fermentasi) memberikan pengaruh positif. Interaksi kuadratik yakni $x_{12}$ dan $x_{22}$ merupakan interaksi antagonis dimana untuk fungsi kuadratik pada lama $\left(x_{1}\right)$ dan suhu fermentasi $\left(x_{2}\right)$ lebih besar dari kondisi optimumnya akan menurunkan nilai IPA, sedangkan interaksi antar 2 faktor yaitu $x_{1} x_{2}$ merupakan interaksi sinergis.

Grafik contour dan grafik surface hasil plot antara lama dan suhu fermentasi dengan IPA disajikan pada Gambar 1a dan Gambar 1b. Gambar 1a menunjukkan plot contour yang dihasilkan terdiri dari berbagai variasi warna. Dimana masing-masing variasi menunjukkan range besarnya respon yang dihasilkan. Range warna inilah yang akan memberigaris besar petunjuk letak titik optimum variabel. Kondisi paling maksimal untuk plot di atas berada di warna hijau tua dengan nilai IPA di atas 2 . Gambar 1b menunjukkan plot surface dalam tiga dimensi. Respon yang optimal dari kombinasi levellevel variabel proses ditentukan dengan menggunakan grafik hasil response optimizer yang disajikan pada Gambar 2.

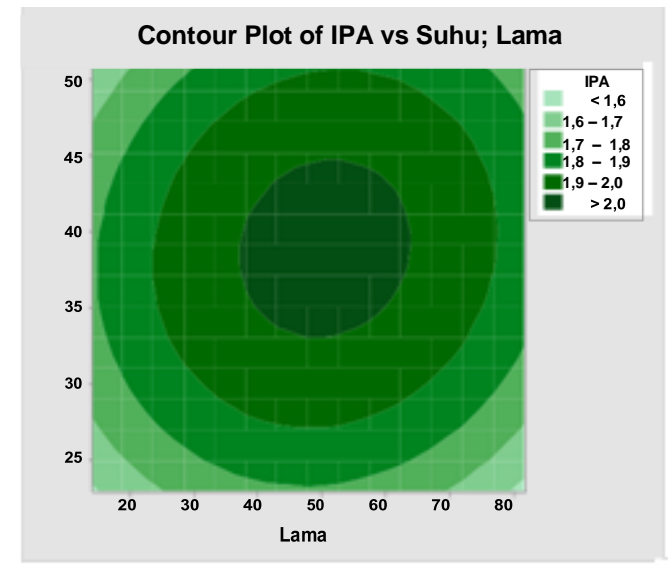

(a)

\section{SurfaceP lot of IP A vsS uhu; Lama}

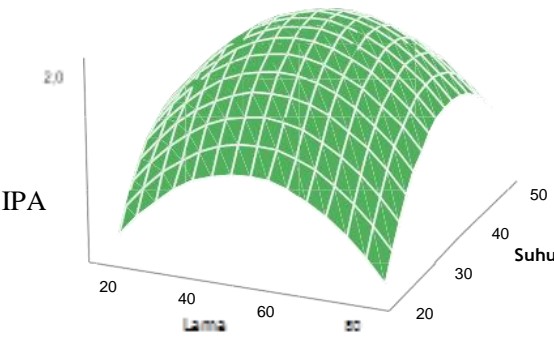

(b)

Gambar 1. a. Contour Plot IPA dan (b) Surface Plot IPA dengan suhu dan lama fermentasi

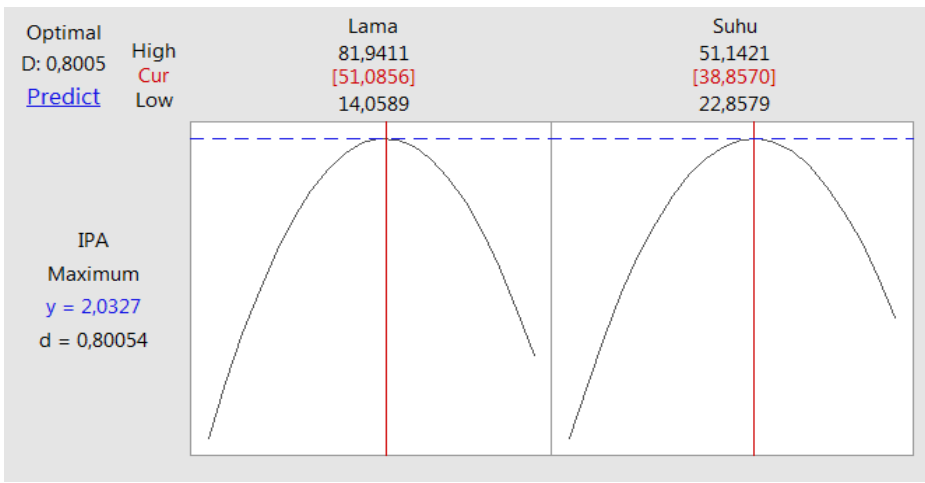

Gambar 2. Hasil grafik response optimizer untuk IPA 
Gambar 2 menunjukkan lama dan suhu optimum adalah pada lama fermentasi 51,08 jam dengan suhu $38,85^{\circ} \mathrm{C}$ dengan menghasilkan IPA sebesar 2,03 g/g. Pada kondisi fermentasi tersebut diduga Lactobacillus plantarum optimal untuk memproduksi protease. Fermentasi dapat meningkatkan penyerapan air di mana selama fermentasi aktivitas proteolitik mikroorganisme memiliki peran penting dalam penambahan gugus polar. Penambahan gugus polar menyebabkan peningkatan hidrofilitas tepung protein (Etudaiye et al., 2009). Pada lama fermentasi lebih dari 51,08 jam, diduga senyawa-senyawa yang memiliki gugus polar hasil pemecahan molekul protein mulai terdegradasi dan larut dalam air perendaman sehingga terjadi penurunan penyerapan air.

\section{Swelling Power}

Daya pembengkakan (swelling power) adalah kekuatan tepung untuk mengembang. Pada respon swelling power nilai p-value untuk model linier lebih besar dari $\alpha=5 \%$ yaitu 0,150 sedangkan $p$-value untuk model square adalah 0,006 atau lebih kecil dari $\alpha=5 \%$ sehingga dapat disimpulkan bahwa model yang tepat untuk respon densitas kamba adalah square (kuadratik). Untuk kecocokan model, dapat dilihat $p$-value dari model $=0,021$ lebih kecil dari derajat signifikansi $\alpha=5 \%$, hal ini berarti faktor-faktor (variabel independen) memberikan pengaruh yang berarti dalam model sedangkan $p$ value lack-of-fit lebih besar dari $\alpha=5 \%$ yaitu 0,283 artinya tidak ada ketidaksesuaian dalam model. Model yang diperoleh dari percobaan untuk swelling power(y) adalah:

$y=2,391+0,02671 \mathrm{x}_{1}+0,1085 \mathrm{x}_{2}-0,000240 \mathrm{x}^{2}-$

$0,001283 \mathrm{x}^{2}-0,000140 \mathrm{x}_{1} \mathrm{x}_{2}$
Berdasarkan persamaan diatas, $x_{1}$ (lama) dan $x_{2}$ (suhu fermentasi) memberikan pengaruh positif, peningkatan suhu dan lama akan meningkatkan swelling volume, namun interaksi kuadratik yakni $x_{1}$ dan $x_{2}$ serta interaksi antar 2 faktor yaitu $x_{1} x_{2}$ merupakan interaksi antagonis, meningkatnya interaksi suhu dan lama fermentasi akan cenderung menurunkan swelling volume tepung kacang nagara hasil fermentasi L. plantarum.

Grafik contour dan grafik surface hasil plot antara swelling power dengan lama dan suhu fermentasi disajikan pada Gambar 3a dan Gambar 3b.

Berdasarkan Gambar 3a, kondisi paling maksimal untuk plot diatas berada di warna hijau tua dengan nilai swelling power diatas 5,1 sedangkan Gambar 3b menunjukkan plot surface dalam tiga dimensi. Respon yang optimal dari kombinasi levellevel variabel proses ditentukan dengan grafik hasil response optimizer yang disajikan pada Gambar 4 . Gambar 4 menunjukkan bahwa lama dan suhu fermentasi optimum adalah pada lama fermentasi 44,24 jam dengan suhu $39,71^{\circ} \mathrm{C}$ dengan menghasilkan swelling power sebesar $5,14 \mathrm{~g} / \mathrm{g}$.

Swelling power mengindikasikan banyaknya jumlah air yang diserap oleh granula pati. Swelling power sering berkaitan dengan kandungan protein dan patinya, menurut Winarno (1992) pengembangan volume juga dapat dipengaruhi oleh kadar amilosa tepung yang digunakan. Kadar amilosa yang tinggi akan meningkatkan absorpsi air. Amilosa mempunyai struktur yang lurus dan rapat sehingga mudah menyerapair. Menurut Susi et al. (2015b) bahwa proses fermentasi kacang nagara menggunakan L. plantarum menyebabkan peningkatan kadar amilosa tepung kacang nagara $20,48 \%$ bk menjadi $24,02 \%$ bk.

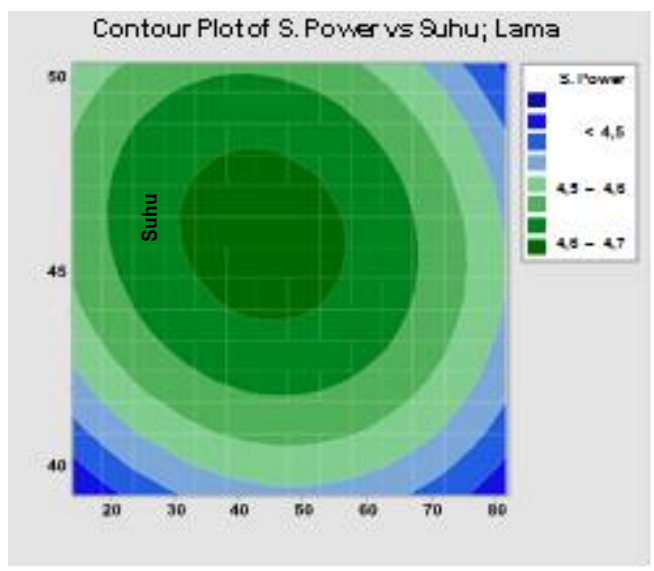

(a)

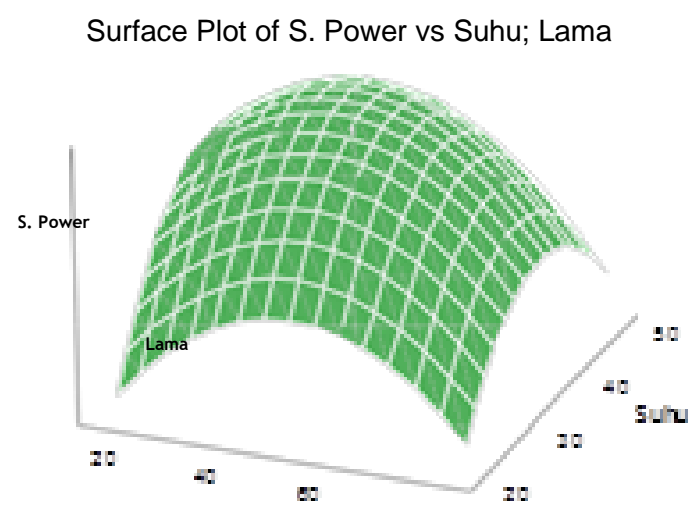

(b)

Gambar 3. (a). Contour Plot Swelling power, (b). Surface Plot Swelling power dengan suhu dan lama fermentasi 


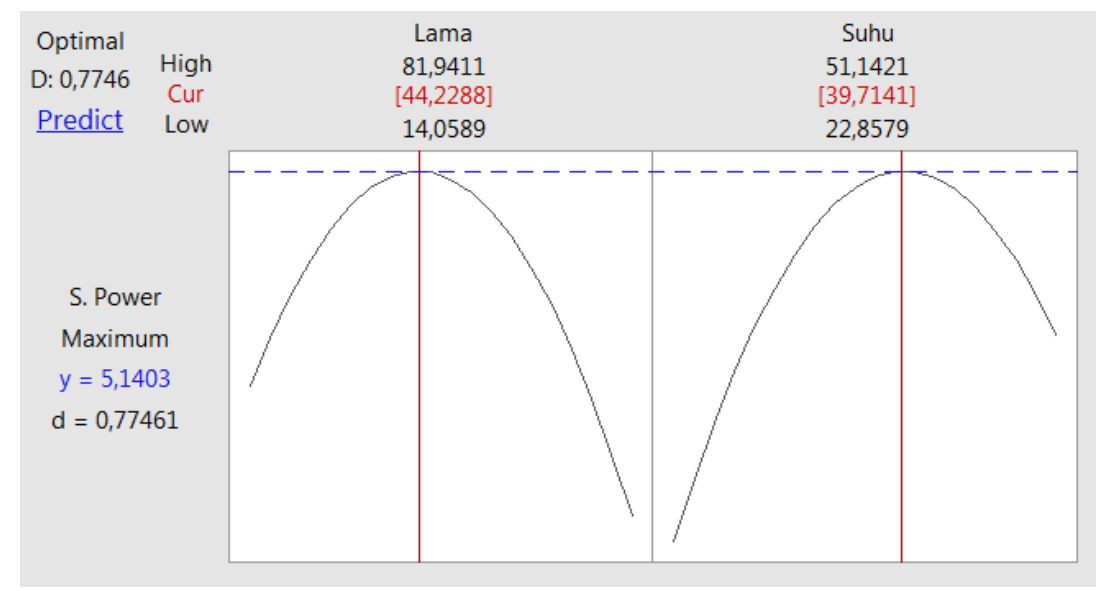

Gambar 4. Hasil grafik response Optimizer untuk Swelling Power

\section{Padatan Tidak Larut}

Padatan tidak larut berkaitan dengan tingkat kelarutan. Padatan tidak larut air yang tinggi menunjukkan bahwa kelarutan rendah. Dari uji parameter regresi diperoleh $\mathrm{p}$-value $=0,038$ atau kurang dari derajat signifikansi $\alpha=5 \%$, hal ini menunjukkan faktor- faktor (variabel bebas) memberi pengaruh yang nyata pada respon. Pada pengujian kesesuaian model dilakukan dengan menggunakan uji Lack-of-Fit. Hipotesis yang digunakan yaitu:

H0 = Tidak ada lack-of-fit dalam model orde I

H1 = Ada lack-of-fit dalam model orde I

Dari hasil analisa data diperoleh lack -offit signifikan $(p$-value $>\alpha)=0,957$ sehingga $\mathrm{H}_{0}$ diterima, artinya terdapat kesesuaian model. Karena kedua parameter uji signifikansi terpenuhi, maka model dinyatakan cocok (linear). Model untuk padatan tidak larut (y) yang diperoleh adalah:

$$
y=78,39+0,1453 x_{1}-0,023 x_{2}
$$

Berdasarkan model diatas, terlihat lama fermentasi berbanding lurus dengan padatan tidak larut, semakin lama proses fermentasi, semakin meningkat padatan tidak larut pada tepung. Penelitian sebelumnya juga menunjukkan bahwa fermentasi hingga 120 jam menurunkan kelarutan padatan dari $20,52 \%$ menjadi $5,91 \%$.

Peningkatan padatan tidak larut dapat terjadi karena penurunan kadar zat padat terlarut. Kadar zat padat terlarut terkait erat dengan kadar gula reduksi dalam suatu bahan. Gula reduksi mempunyai kelarutan yang tinggi sehingga akan meningkatkan kadar zat padat terlarut dalam suatu larutan. Diduga selama fermentasi kacang nagara dengan Lactobacillus plantarum terjadi penurunan kadar gula reduksi pada kacang nagara yang disebabkan oleh pemanfaatan gula reduksi sebagai sumber energi untuk pertumbuhan dan perbanyakan sel serta pembentukan metabolit selama fermentasi.
L. plantarum menghasilkan enzim $\alpha$ - amilase, tepung kacang nagara yang mengalami enzymatic digestion oleh $\alpha$-amilase selama 90 menit terjadi penurunan kadar gula reduksi dari 2,03 mg/mL menjadi 1,86 $\mathrm{mg} / \mathrm{mL}$ (Susi et al., 2017).

Tepung kacang nagara yang selain gula reduksi, protein juga merupakan bagian zat padat terlarut.Pada fermentasi kacang nagara dengan Lactobacillus plantarum yang dilakukan Susi et al. (2015b), terjadi kecenderungan penurunan nilai protein terlarut dengan semakin lamanya fermentasi yang dilakukan. Kelarutan protein sangat dipengaruhi oleh $\mathrm{pH}$ isoelektriknya. Selama fermentasi, Lactobacillus plantarum menghasilkan asam laktat sehingga akan terjadi perubahan $\mathrm{pH}$ seiring lamanya fermentasi. Pada saat protein mencapai $\mathrm{pH}$ isoelektriknya, protein akan mengalami pengendapan (koagulasi) dan menurunkan kelarutannya (Sirajuddin dan Najamuddin, 2011).

\section{Kadar Air}

Kadar air suatu produk sangat penting dikendalikan karena akan menentukan daya tahan atau keawetan produk yang bersangkutan pada waktu penyimpanan. Kerusakan bahan makanan pada umumnya merupakan proses mikrobiologis, kimiawi, enzimatik atau kombinasi antara ketiganya. Berlangsungnya ketiga proses tersebut memerlukan air bebas yang dapat membantu berlangsungnya proses tersebut.

Menurut Phattra dan Maweang (2015), proses fermentasi mampu mengubah granula pati menjadi lebih kasar dan memiliki permukaan yang porous karena ekso korosi oleh hidrolisis enzim yang menyerang permukaan dan membentuk pori serta terjadi degradasi bagian luar granula. Hal ini diduga berkorelasi dengan mudahnya air bebas dari matriks tepung untuk menguap pada saat pengeringan karena makin banyak pori yang terbentuk selama proses fermentasi. 
Berdasarkan hasil ANOVA tidak satupun model baik linear maupun square (kuadratik) yang tepat untuk respon kadar air. Hal ini dilihat dari nilai p-value untuk model linier maupun square lebih besar dari $\alpha=5 \%$, ini menunjukkan faktor-faktor (variabel bebas) yaitu lama dan suhu fermentasi tidak memberikan pengaruh yang berarti terhadap kadar air sehingga kadar air tepung kacang nagara hasil fermentasi menggunakan L. plantarum tidak dapat dioptimalkan dengan perlakuan lama dan suhu fermentasi. Model yang diperoleh dari percobaan orde II untuk kadar air (y) adalah:

$\mathrm{y}=14,33-0,1581 \mathrm{x}_{1}-0,139 \mathrm{x}_{2}+0,000346 \mathrm{x}^{2}+$ $0,00009 \mathrm{x}^{2}+0,003351 \mathrm{x}_{1} \mathrm{x}_{2}$

Kadar abu tepung kacang nagara yang dihasilkan berkisar antara 1,11-3,04\% cenderung lebih kecil dari pada kadar abu kacang nagara segar yaitu 3,35\%. Menurut Aini et al. (2009), selama fermentasi akan terjadi penurunan kadar abu yang disebabkan lepasnya mineral pada waktu perendaman, yaitu terjadi leaching sebagian mineral dalam bentuk ion bebas pada air perendaman.

\section{Kadar Lemak}

Hasil uji parameter regresi diperoleh pvalue $=0,008$ atau kurang dari derajat signifikansi $\alpha$ $=5 \%$, hal ini menunjukkan faktor- faktor (variabel bebas) memberi pengaruh yang nyata pada respon. Akan tetapi berdasarkan koefisien regresi linear secara individu, hanya faktor lama fermentasi yang memberi pengaruh terhadap model karena $p$-value suhu fermentasi lebih dari derajat signifikansi $\alpha=$ $5 \%$ yaitu 0,497 sehingga suhu fermentasi tidak mempengaruhi kadar lemak. Pada pengujian kesesuaian model dilakukan dengan menggunakan uji lack-of-fit. Hipotesis yangdigunakan:

H0 = Tidak ada lack-of-fit dalam model orde I

H1 = Ada lack-of-fit dalam model orde I

Dari hasil analisa data diperoleh lack -offit tidak signifikan $(\mathrm{p}$-value $>\alpha)=0,338$ sehingga H0 diterima, artinya terdapat kesesuaian model.
Karena kedua parameter uji signifikansi terpenuhi, maka model yang terpilih untuk kadar lemak (y) adalah linier yaitu:

$$
y=6,81-0,0495 x 1-0,0177 \times 2
$$

Berdasarkan model diatas terlihat bahwasanya lama maupun suhu fermentasi memberikan pengaruh antagonis (berbanding terbalik) pada kadar lemak tepung kacang nagara hasil fermentasi menggunakan L. plantarum. Semakin lama fermentasi dan meningkatnya suhu fermentasi akan berpengaruh terhadap semakin rendahnya kadar lemak tepung kacang nagara yang dihasilkan. Kadar lemak kacang nagara segar adalah 5,64\% sedangkan kadar lemak tepung kacang nagara yang dihasilkan cenderung lebih rendah yaitu 2,8\% $5,53 \%$. Menurut Pangastuti et al. (2013) perendaman selama fermentasi dapat mengaktifkan aktivitas enzim lipase yang menghasilkan beberapa asam lemak bebas rantai pendek yang mudah larut ke dalam air pada media perendaman sehingga terjadi penurunan kadar lemak.

\section{Kadar Protein}

Pada umumnya kadar protein di dalam bahan pangan menentukan mutu bahan pangan itu sendiri terutama pada kacang-kacangan sebagai sumber protein nabati. Di samping berfungsi sebagai bahan bakar dalam tubuh, protein juga berfungsi sebagai zat pembangun dan pengatur serta sebagai imunitas dalam tubuh. Grafik contour dan grafik surface hasil plot antara protein dengan lama dan suhu fermentasi disajikan pada Gambar 5a dan Gambar 5b. Pada Gambar 5a, kondisi paling maksimal untuk plot berada di warna hijau tua dengan nilai kadar protein di atas $25 \%$, sedangkan Gambar 5b menunjukkan plot surface dalam tiga dimensi dimana besarnya faktor variabel independen $\mathrm{x} 1$ (lama fermentasi) dan $\mathrm{x} 2$ (suhu fermentasi) yang mengoptimalkan respon tidak terlihat jelas karena hasil yang diperoleh berupa range data yang cukup besar.

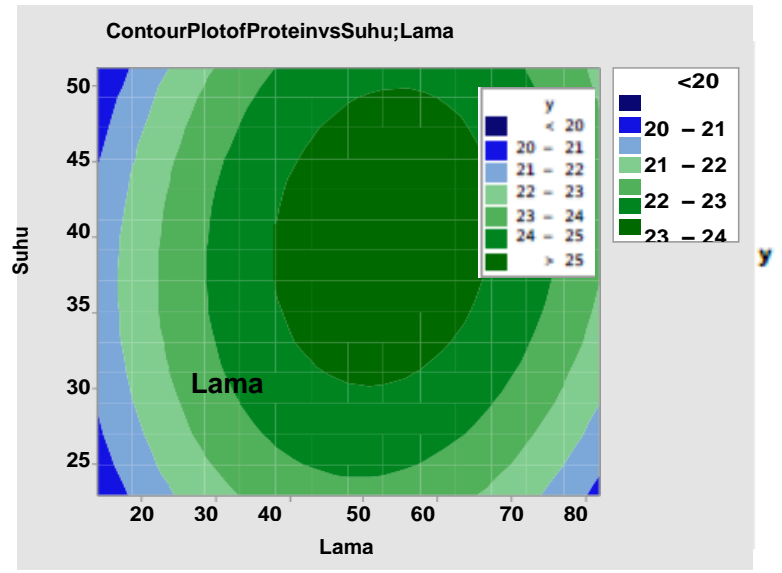

Surface Plot of Protein vs Suhu; Lama

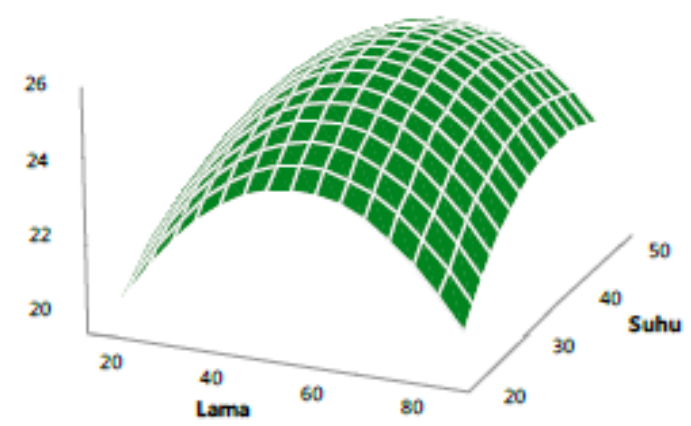

Gambar 5. (a). Contour Plot kadar protein dan (b). Surface Plot dengan suhu dan lama fermentasi 
Kombinasi level-level variabel proses yang dapat menghasilkan respon yang optimal ditunjukkan pada grafik hasil response optimizer yang disajikan pada Gambar 6.

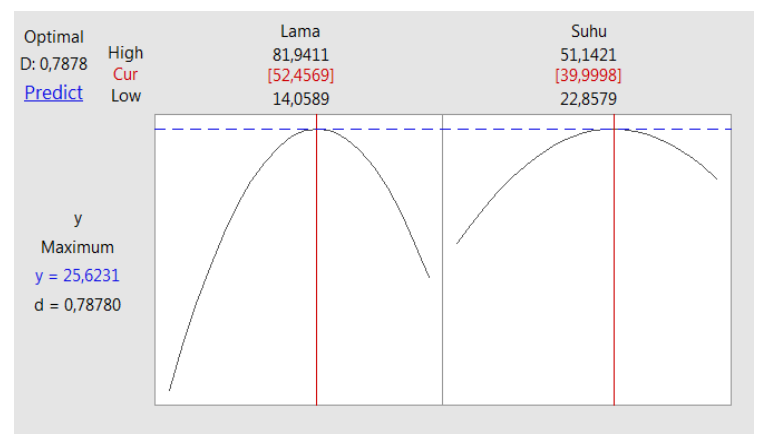

Gambar 6. Grafik response optimizer untuk kadar protein

Gambar 6 menunjukkan bahwa lama dan suhu fermentasi optimum adalah pada lama fermentasi 52,45 jam dengan suhu $40^{\circ} \mathrm{C}$ dengan menghasilkan kadar protein sebesar 25,62\%. Menurut Tandrianto (2014) peningkatan jumlah protein pada pembuatan MOCAF dengan Lactobacillus plantarum disebabkan oleh adanya pertambahan jumlah mikroorganisme yang berperan sebagai Single cell protein (SCP), yaitu protein yang didapat dari mikroorganisme. Hal ini sesuai dengan pendapat Nurhayani et al. (2000), peningkatan jumlah massa mikroba akan menyebabkan peningkatan kandungan produk fermentasi, dimana kandungan protein merupakan refleksi dari jumlah massa sel dimana dalam proses fermentasi mikroba akan menghasilkan enzim yang akan mendegradasi senyawa-senyawa komplek menjadi lebih sederhana, dan mikroba juga akan mensintesis protein yang merupakan proses protein enrichment yaitu pengkayaan protein bahan.

Selama proses fermentasi, Lactobacillus plantarum menghasilkan enzim ekstraseluler (protease). Protease akan menghidrolisis protein menjadi peptida yang sederhana seperti menjadi oligopeptida pendek atau asam amino sehingga protein akan mudah berdifusi dan larut pada air perendaman. Hal ini diduga menyebabkan lama fermentasi lebih dari 52,45 jam terjadi penurunan kadar protein. Asam amino polar yang terdapat pada kacang nagara adalah asam aspartat, asam glutamat, serin, histidin, arginin, threonin, tirosin, sistin dan lisin (Susi et al., 2015a).

\section{Kadar Karbohidratby Difference}

Karbohidrat merupakan komponen utama dalam tepung-tepungan. Menurut Winarno (1992) karbohidrat mempunyai peranan penting dalam menentukan karakteristik bahan makanan, misalnya rasa, warna, tekstur dan lain-lain. Berdasarkan hasil ANOVA, tidak satupun model baik linear maupun square (kuadratik) yang tepat untuk respon kadar karbohidrat. Hal ini dilihat dari nilai p-value untuk model linier maupun square lebih besar dari $\alpha=5 \%$, ini menunjukkan faktor-faktor (variabel bebas) yaitu lama dan suhu fermentasi tidak memberikan pengaruh yang berarti terhadap kadar karbohidrat sehingga kadar karbohidrat tepung kacang nagara hasil fermentasi menggunakan L. plantarumtidak dapat dioptimalkan dengan perlakuan lama dan suhu fermentasi. Model yang diperoleh untuk kadar karbohidrat by difference(y) adalah:

$$
\begin{aligned}
& y=5,97+0,097 \times 1-0,039 \times 2+0,001988 \times 2+ \\
& 0,00438 \times 2-0,00672 \times 1 \times 2
\end{aligned}
$$

Penelitian sebelumnya menunjukkan bahwa karbohidrat padakacang nagara segar 62\%, kadar karbohidrat pada tepung kacang nagara hasil fermentasi menggunakan L. plantarumyang dihasilkan dari proses optimasirelatif tidak jauh berbeda yaitu berkisar 59,60\% - 65,75\%.

Beberapa respon tidak cocok dengan model linear ataupun model kuadratik. Hal ini menunjukkan lama dan suhu fermentasi tidak memberi pengaruh nyata terhadap respon. Respon tersebut yaitu densitas kamba, kadar air, kadar abu dan kadar karbohidrat.

Banyak faktor yang terlibat dan mempengaruhi respon selama proses fermentasi diantaranya,enzim,nutrisi dan mikroba.Selain mikroba yang ditambahkan sebagai starter (Lactobacillus plantarum), mikroflora alami (indigenous) dari kacang nagara juga terlibat dalam proses fermentasi. Pertumbuhan mikroba dan jenisnya dipengaruhi oleh $\mathrm{pH}$, suhu dan ketersediaan nutrisi. Setiap mikroba memiliki $\mathrm{pH}$ optimum yang berbeda-beda, oleh karena itu $\mathrm{pH}$ selama fermentasi sangat menentukan mikroba yang dominan selama fermentasi dan selanjutnya akan mempengaruhi enzim yang aktif dan nutrisi yang tersedia/hasil metabolit.

Enzim yang diduga terlibat selama fermentasi kacang nagara dengan Lactoacillus plantarum adalah fitase (Saribuga et al.,2014; Sumengen et al., 2013), lipase (Uppada et al., 2017; Lopes et al., 1999), protease (Utami et al., 2015; Matthews et al., 2004), pululanase (Vishnu et al., 2006) dan amilase (Onilude et al., 2017; Sanni et al., 2002). Tiap enzim memerlukan suhu dan $\mathrm{pH}$ (tingkat keasaman) optimum yang berbeda-beda karena enzim adalah protein, yang dapat mengalami perubahan bentuk jika suhu dan keasaman berubah (Subagiyo et al., 2016; Peterson et al., 2007). Di luar suhu atau $\mathrm{pH}$ yang sesuai, enzim tidak dapat bekerja secara optimal atau strukturnya akan mengalami kerusakan. Selama proses fermentasi $\mathrm{pH}$ berfluktuasi seiring proses fermentasi.

Menurut Kusmiati dan Malik (2002), mikroba dalam kehidupannya membutuhkan makronutrien dan mikronutrien. Salah satu makronutrien yang dibutuhkan adalah sumber 
karbon yang berguna untuk tumbuh, berkembang biak, sumber energi dan sebagai cadangan makanan. Jenis dan jumlah sumber karbon sangat mempengaruhi pertumbuhan bakteri yang secara tidak langsung mempengaruhi sintesa metabolit sekunder.

Optimasi Lama dan Suhu Fermentasi untuk menghasilkan Tepung Kacang dengan Kualitas Terbaik

Untuk menentukan kondisi optimal lama dan suhu fermentasi yang menghasilkan tepung kacang nagara dengan kualitas terbaik perlu diperhatikan masing-masing respon yang signifikan terhadap model kuadratik karena hanya respon yang signifikan terhadap model kuadratik yang dapat ditentukan kondisi optimumnya. Kecocokan model masing-masing respon baik fisik maupun kimia dapat dilihat pada Tabel 2.

Berdasarkan Tabel 2, indeks penyerapan air (IPA), swelling power dan kadar protein signifikan terhadap model kuadratik sehingga penentuan lama dan suhu fermentasi yang optimum dilakukan dengan menggabungkan ketiga respon tersebut (multi respon) sehingga didapatkan lama dan suhu yang optimal terhadap ketiga respon. Kombinasi level-level variabel proses yang dapat menghasilkan respon IPA, swelling power dan kadar protein yang optimal dapat dilihat pada grafik hasil response optimizer yang disajikan pada Gambar 7. Pada Gambar 7 ditunjukkan bahwa lama dan suhu fermentasi optimum adalah pada lama fermentasi 49,71 jam dengan suhu $39,14^{\circ} \mathrm{C}$ dengan menghasilkan IPA sebesar 2,03, swelling power sebesar 5,13 dan kadar protein sebesar 25,60\%.

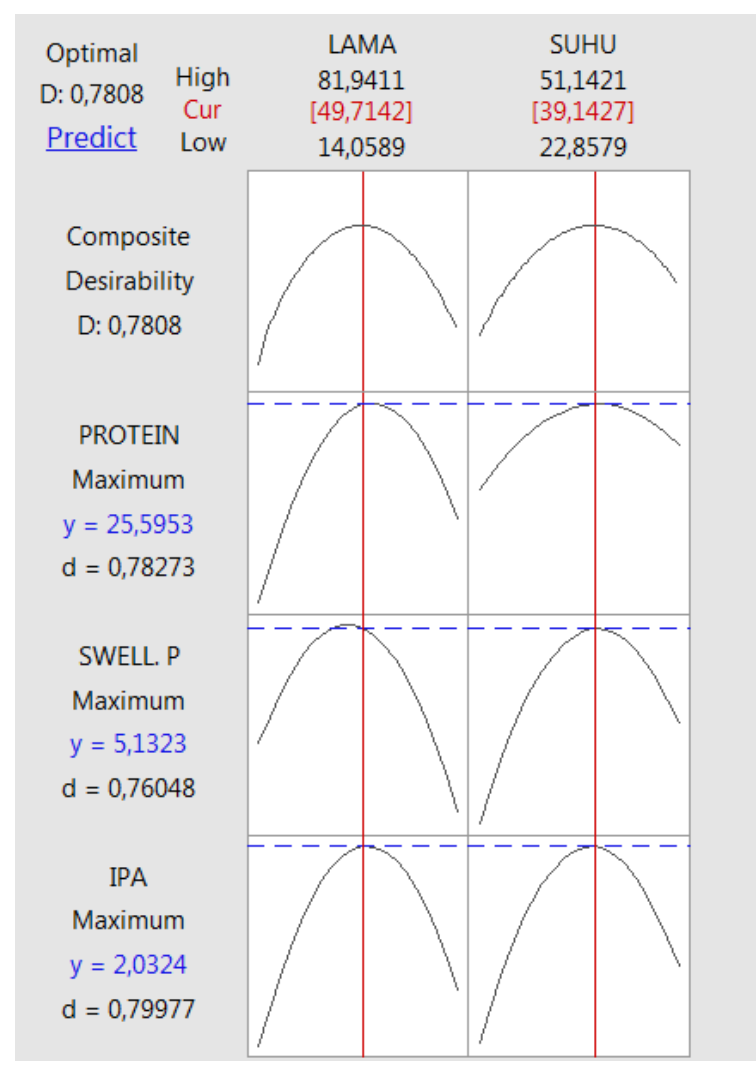

Gambar7. Hasil grafik response optimizer untuk IPA, swelling power dan kadar protein

Pada Gambar 7 ditunjukkan bahwa lama dan suhu fermentasi optimum adalah pada lama fermentasi 49,71 jam dengan suhu $39,14^{\circ} \mathrm{C}$ dengan menghasilkan IPA sebesar 2,03, swelling power sebesar 5,13 dan kadar protein sebesar 25,60\%.

Tabel 2. Kecocokan respon terhadap model linear dan kuadratik

\begin{tabular}{|c|c|c|c|c|c|c|c|}
\hline \multirow[b]{2}{*}{ Respon } & \multirow[b]{2}{*}{$\begin{array}{c}\text { Rentang Nilai } \\
\text { Respon }\end{array}$} & \multicolumn{2}{|c|}{ Model } & \multicolumn{3}{|c|}{ Kondisi Optimum } & \multirow{2}{*}{$\begin{array}{c}\text { Kondisi } \\
\text { sebelum } \\
\text { optimasi }^{\text {a) }}\end{array}$} \\
\hline & & Linear & Kuadratik & $\begin{array}{c}\text { Lama } \\
\text { (jam) }\end{array}$ & $\begin{array}{c}\text { Suhu } \\
\left({ }^{\circ} \mathrm{C}\right)\end{array}$ & $\begin{array}{c}\text { Nilai } \\
\text { Respon }\end{array}$ & \\
\hline \multicolumn{8}{|l|}{ Kualitas Fisik: } \\
\hline Densitas Kamba & $0,62-0,74 \mathrm{~g} / \mathrm{mL}$ & TS & TS & - & - & - & 0,53 \\
\hline IPA & $1,7-2,03$ & TS & $\mathrm{S}$ & 51,08 & 38,85 & 2,03 & 1.98 \\
\hline Swelling Power & $4,7-5,26$ & TS & S & 44,22 & 39,71 & 5,14 & 7.39 \\
\hline $\begin{array}{l}\text { Padatan tidak } \\
\text { larut }\end{array}$ & $80,61-88,05 \%$ & $\mathrm{~S}$ & $\mathrm{TS}$ & - & - & - & $87.98 \%$ \\
\hline \multicolumn{8}{|l|}{ Kualitas Kimia: } \\
\hline Kadar Air & $8-9,9 \%$ & $\mathrm{TS}$ & TS & - & - & - & $5,97 \%$ \\
\hline Kadar Abu & $1,11-3,04 \%$ & TS & $\mathrm{TS}$ & - & - & - & - \\
\hline Kadar Lemak & $2,8-5,53 \%$ & $\mathrm{~S}$ & TS & - & - & - & $2,18 \%$ \\
\hline Kadar Protein & $21,3-26,79 \%$ & TS & S & 52,45 & 40 & $25,62 \%$ & $20,41 \%$ \\
\hline Kadar KH & $59,59-65,75 \%$ & TS & $\mathrm{TS}$ & - & - & - & $74,73 \%$ \\
\hline
\end{tabular}

Keterangan : $\mathrm{TS}=$ tidak signifikan; $\mathrm{S}=$ signifikan

$$
\text { (a) = Susi et al. (2015) }
$$




\section{KESIMPULAN DAN SARAN}

\section{Kesimpulan}

Lama dan suhu fermentasi optimum menggunakan Lactobacillus plantarum untuk modifikasi tepung kacang nagara adalah pada lama fermentasi 49,71 jam dan suhu fermentasi 39,14oC dengan menghasilkan menghasilkan indeks penyerapan air (IPA) sebesar 2,03, swelling power sebesar 5,13 dan kadar protein sebesar 25,60\%. Namun, variasi lama dan suhu fermentasi tersebut belum mampu mengoptimalkan respon densitas kamba, padatan tidak larut, kadar air, kadar abu, kadar lemak dan kadar karbohidrat karena faktor tidak memberikan pengaruh yang nyata terhadap respon.

\section{Saran}

Disarankan adanya penelitian lanjutan dengan memanfaatkan hasil penelitian ini untuk diolah menjadi produk tertentu ataupun mengkaji substitusi terigu dengan tepung kacang nagara termodifikasi pada kondisi optimum yang didapatkan.

\section{DAFTAR PUSTAKA}

Ade-Omowaye BIO, Akinwande BA, Bolarinwa IF, Adebiyi AO. 2008. Evaluation of tigernut (Cyperus esculentus)-wheat composite flour andbread. Africa Journal Food Science. 2:087-091.

Adeleke RO dan Odedeji JO. 2010. Functional properties of wheat and sweet Potato flour blends. Pakistan Journal Nutr. 9 (6): 535538.

Afriani. 2010. Pengaruh penggunaan starter bakteri asam laktat Lactobacillus plantarum dan Lactobacillus fermentum terhadap total bakteri asam laktat, kadar Asam dan nilai $\mathrm{pH}$ dadih susu sapi. Jurnal Ilmiah IlmuIlmu Peternakan.XIII (6): 279-285.

Aini N, Hariyadi P, Muchtadi TR, Andarwulan N. 2009. Hubungan sifat kimia dan rheologi tepung jagung putih dengan fermentasi spontan butiran jagung.[Disertasi]. Bogor: Institut Pertanian Bogor.

Akbar MR dan Yunianta. 2013. Pengaruh lama perendaman $\mathrm{Na} 2 \mathrm{~S} 2 \mathrm{O} 5$ dan fermentasi ragi tape terhadap sifat fisik kimia tepung jagung. Jurnal Pangan dan Agroindustri. 2 (2): $91-102$

AOAC. 2000. Official Methods of Analysis. 17th Ed., Gaithersburg, MD US: The Association of Official Analytical Chemists.

Astawan M. 2009. Sehat dengan Hidangan Kacang dan Biji-Bijian. Jakarta: Penebar Swadaya.

Bergey DH, dan Boone DR. 2009. Bergey's Manual of Systematic Bacteriology. 2nd ed. United
States of America: The Firmicutes. Springer.

Etudaiye HA, Nwabuaze TU, dan Sanni LO. 2009. Quality of fufu processed from cassava mosaic disaese (CMD) resistant varietier. African J Food Sci. 3 (3): 061-067.

Gunawan. T, Widjaja S, Zullaikah L, Ernawati N, Istianah W, Aparamarta HD, Prasetyoko. 2015. Effect of fermenting cassava with Lactobacillus plantarum, Saccharomyces cereviceae, and Rhizopus oryzae on the chemical composition of their flour. Intern. Food Res Journal. 22 (3) : 1280-1287.

Kusmiati dan Malik A. 2002. Aktivitas bakteriosin dari bakteri Leuconostoc mesenteroides Pbac1 pada berbagai Media. Jurnal Makara Kesehatan. 1 (6) :1-7.

Mangalisu A, Nahariah, dan Hatta W. 2015. Kemampuan fermentasi Lactobacillus plantarum pada telur infertil dengan waktu inkubasi yang berbeda. JITP. 4 (2): 70-73

Matthews A, Grimaldi A, Walker M, Bartowsky E, Grbin P, Jiranek V. 2004. Lactic acid bacteria as a potential source of enzymes for use in vinification. Appl Environ Microbiol. 70(10): 715-5731.

Meyer LH. 1996. Food Chemistry. New York: Teinhold Publishing Co.

Muchtadi TR, Haryadi P, dan Ahza AB. 1988. Teknologi Pemasakan Ekstrusi. Bogor: PAU Pangan dan Gizi. Institut Pertanian Bogor.

Nguyen TTT, Loiseau G, Verniere CI, Rochette I, Treche S, Guyo JP. 2007. Effects of fermentation by amylolytic lactic acid bacteria, in process combinations, on characteristics of rice/soybean slurries: a new method for preparing high energy density complementary foods for young children. Food Chemical. 100:623-631.

Nowroozi J, Mirazaii M, dan Norouzi M. 2004. Study of Lactobacillus as probiotic bacteria. Iranian Journal pub Health 33:1-7.

Nurani D, Sukotjo S, dan Nurmalasari S. 2013. Optimasi proses produksi tepung talas (Colocasia esculenta, L. Schott) termodifikasi secara fermentasi. J IPTEK.8 (1): $65-7$.

Nurhayani H, Muhiddin, Nuryati J, Aryantha INP. 2000. Peningkatan kandungan protein kulit umbi ubi kayu melalui proses fermentasi. JMS.6(1):1 -12.

Onilude AA, Ayinla GS, dan Eluehike C. 2017. Properties of alpha-amylase of Lactobacillus plantarum isolated from cassava waste samples. Biotechnol Journal Intern. 19(1): 1-14.

Pangastuti HA, Affandi DR, dan Ishartani D. 2013. Karakterisasi sifat fisik dan kimia tepung kacang merah (Phaseolus vulgaris l.) 
dengan beberapa perlakuan pendahuluan. Jurnal Teknosains Pangan.2 (1).

Peterson ME, Daniel RM, Danson MJ, Eisenthal R. 2007. The dependence of enzyme activity on temperature: determination and validation of parameters. Biochemical Journal. 402:331-337.

Phattra B dan Maweang M. 2015. Effect of natural fermentation on the rice slurry properties related to rice paper production. Journal Food Science Agr Tech. 1 (1): 22-25.

Putri DWR, Haryadi DW, Marseno, Cahyanto MN. 2011. Effect of biodegradation by lactic acid bacteria on physical properties of cassava starch. International Food Res Journal 18 (3) : 1149-1154.

Sanni Al, Morlon-Guyot J, dan Guyot JP. 2002 New efficient amylase-producing strain of Lactobacillus plantarum and L. fermentum isolated from different Nigerian traditional fermented foods. International Journal Food Microbiol. 72(1-2):53-62.

Sarıbuga E, Nadaroglu H, Dikbas N, Merve Senol, Cetin B. 2014. Purification, characterization of phytase enzyme from Lactobacillus plantarum bacteria and determination of its kinetic properties. African Journal Biotechnol. 13(23) :2373-2378.

Schubert. 1987. Food article technology. Part 1: Properties of particle and particulate food system. Journal Food Engginering. 6: 1-32.

Setiarto RHB, Jenie BSL, Faridah DN, Saskiawan I, Sulistiani. 2015. Seleksi bakteri asam laktat penghasil amilase dan pululanase dan aplikasinya pada fermentasi talas. Jurnal Teknologi dan Industri Pangan. 26(1): 8089.

Sirajuddin S dan Najamuddin U. 2010. Penuntun Praktikum Biokimia. Makassar : Fakultas Kesehatan Masyarakat Universitas Hasanuddin.

Silva Lopes MF, Cunha A, Clemente JJ, Carrondo MJT, Crespo MTB. 1999. Influence of environmental factors on lipase production by Lactobacillus plantarum. Appl Microbiol Biotechnol. 51(2): 249-254.

Subagiyo, Nuraeni RAT, Setyati WA, Santoso A. 2016. Optimasi suhu dan $\mathrm{pH}$ pertumbuhan Lactococcus lactis isolat ikan kerapu. Jurnal Kelautan Tropis. 19(2):166-170.

Suhanda I. 2009. Rahasia Sehat dengan Makanan Berkhasiat. Jakarta: Kompas.
Sumengen M, Dincer S, dan Kaya A. 2013. Production and characterization of phytase from Lactobacillus plantarum. Food Biotech. 27(2):105-118.

Susi, Agustina L, dan Sari SG. 2017. Pengembangan ready to eat breakfast cereal berbasis bahan lokal tepung kacang nagara termodifikasi bakteri laktat untuk meningkatkan gizi anak. [Laporan Penelitian Hibah Pekerti]. Banjarmasin: Universitas Lambung Mangkurat.

Susi, Agustina L, dan Wibowo C. 2015a. Potential applications modified nagara bean flour through Fermentation for innovation analog rice high protein.Proceedings of $20153^{\text {rd }}$ International Conference on Adaptive and Intelligent Agroindustry (ICAIA). IPB Bogor, Indonesia. 3-4 August 2015.

Susi, Agustina L, dan Wibowo C. 2015b. Modifikasi tepung kacang nagara melalui fermentasi bakteri asam laktat untuk produksi beras analog dalam rangka meningkatkan ketahanan pangan. [Laporan Penelitian Hibah Pekerti]. Banjarmasin: Universitas Lambung Mangkurat.

Tandrianto J, Mintoko DK, dan Gunawan S. 2014. Pengaruh fermentasi pada pembuatan mocaf (modified cassava flour) dengan menggunakan Lactobacillus plantarum terhadap kandungan protein. Jurnal Teknik POMITS.3 (2): 143-145.

Uppada SR, Akula M, Bhattacharya A, Dutta JR. 2017. Immobilized lipase from Lactobacillus plantarum in meat degradation and synthesis of flavor esters. Journal Genet Engand Biotechnol. 15: 331-334.

Utami T, Nurhayati R, dan Rahayu ES. 2015. The effect of addition of Lactobacillus plantarrum S4512 on the microbiological and chemical characteristics during sorghum (Sorghum bicolor L. Moench) fermentation. AGRITECH 35(4):449-455

Vishnu C, Naveena BJ, Altaf M, Venkateshwar M, Reddy G. 2006. Amylopullulanase-A novel enzyme of $L$. amylophilus GV6 in direct fermentation of starch to $\mathrm{L}(+)$ lactic acid. Enzyme Microb Technol. 38 (3-4):545550,doi 10.1016

Winarno FG. 1992. Kimia Pangan dan Gizi. Jakarta: Gramedia. 